\title{
The role of pit corrosion in engineering the carbon storage site at Ketzin, Germany
}

\author{
A. Pfennig ${ }^{1} \&$ A. Kranzmann ${ }^{2}$ \\ ${ }^{1} H T W$ University of Applied Sciences Berlin, Germany \\ ${ }^{2}$ BAM Federal Institute of Materials Research and Testing, Germany
}

\begin{abstract}
The role of pit corrosion needs to be considered to guarantee reliability and safety during the injection of compressed emission gasses - mainly containing $\mathrm{CO}_{2}$ - into deep geological layers (CCS-technology, Carbon Capture and Storage). Therefore, laboratory experiments were carried out under the distinct synthetic aquifer environment saturated with technical $\mathrm{CO}_{2}$ at a flow rate of $2 \mathrm{l} / \mathrm{h}$ found at the CCS-site at Ketzin, Germany. To determine the local corrosion behaviour, different pipe steels with $1 \% \mathrm{Cr} 0.42 \% \mathrm{C}(42 \mathrm{CrMo} 4)$ and $13 \% \mathrm{Cr}$ $0.46 \% \mathrm{C}(\mathrm{X} 46 \mathrm{Cr} 13)$ were compared. The samples were heat treated for up to 2 years and the reaction kinetics were determined. Pits were formed exclusively on the high chromium bearing steels. Pit heights and diameters were measured and a precipitation model was derived from the phases found within the complicated multilayer corrosion phases, such as siderite $\mathrm{FeCO}_{3}$ and goethite $\alpha$ $\mathrm{FeOOH}$. Manganese and chromium carbides were found to be possible initial causes for the ongoing pit corrosion.
\end{abstract}

Keywords: steel, pipeline, pit corrosion, $\mathrm{CCS}, \mathrm{CO}_{2}$-injection, $\mathrm{CO}_{2}$-storage.

\section{Introduction}

When engineering the geological CCS-site at Ketzin, Germany $\left(\mathrm{CO}_{2}\right.$-SINK, CCS Carbon Capture and Storage [1, 2]), corrosion of the casing and injection pipe steels may become an issue when emission gasses are compressed from combustion processes into deep geological layers [3-10]. It is known from thermal energy production that the $\mathrm{CO}_{2}$-corrosion is sensitively dependent on alloy composition, the contamination of alloy and media, environmental conditions such as temperature, $\mathrm{CO}_{2}$ partial pressure, flow conditions and 


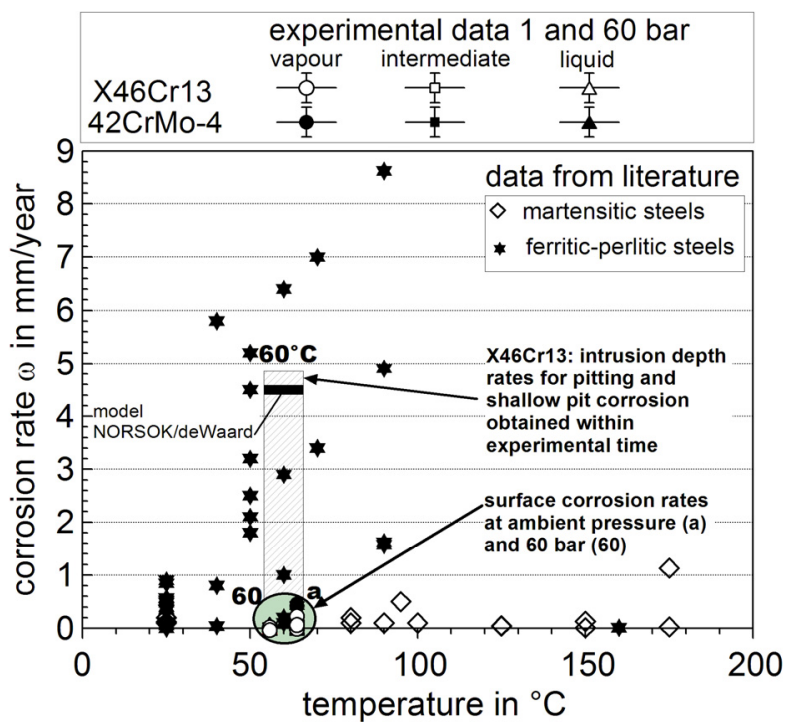

Figure 1: Comparison of measured uniform corrosions rates of 42CrMo-4 and $\mathrm{X} 46 \mathrm{Cr} 13$ (also intrusion depth rates for shallow pit and pitting corrosion) with data obtained from literature [20].

protective corrosion scales [8-18]. Considering different environments, aquifer waters and pressures, the temperature regime between $40{ }^{\circ} \mathrm{C}$ to $60{ }^{\circ} \mathrm{C}$ [19] is a critical temperature region well known for severe corrosion processes, as shown by Pfennig and Bäßler [20, 21] (figure 1).

Figure 1 demonstrates that the intrusion depth for pit corrosion of $13 \% \mathrm{Cr}$ steel $\mathrm{X} 46 \mathrm{Cr} 13$ is a maximum of around $4.7 \mathrm{~mm} /$ year, but may also be predicted by the rather conservative Norsok-Model for the oil and gas industry [22].

Steels exposed to a $\mathrm{CO}_{2}$-environment generally precipitate slow growing surface layers mainly comprised of $\mathrm{FeCO}_{3}$ (siderite) [23]. This phase is also found in pits of locally corroded samples [20,21]. After the $\mathrm{CO}_{2}$ is dissolved to build a corrosive environment, the solubility of $\mathrm{FeCO}_{3}$ in water is low $\left(\mathrm{p}_{\mathrm{Ksp}}=\right.$ 10.54 at $25^{\circ} \mathrm{C}$ ). As a result of the anodic iron dissolution, a siderite corrosion layer grows on the alloy surface $[9,20]$ :

$\begin{array}{llll} & \mathrm{CO}_{2}(\mathrm{~g})+\mathrm{H}_{2} \mathrm{O}(\mathrm{l}) & \rightarrow \mathrm{H}^{+}+\mathrm{HCO}_{3}^{-}(\mathrm{aq}) \\ \text { cathodic: } & 2 \mathrm{HCO}_{3}{ }^{-}+2 \mathrm{e}^{-} & \rightarrow & \rightarrow \mathrm{CO}_{3}{ }^{2-}+\mathrm{H}_{2} \\ \text { anodic: } & \mathrm{Fe} & \rightarrow \mathrm{Fe}^{2+}+2 \mathrm{e}^{-} \\ & \mathrm{Fe}^{2+}+\mathrm{CO}_{3}{ }^{2-} \rightarrow & \mathrm{FeCO}_{3} \\ & \mathrm{Fe}^{2+}+2 \mathrm{HCO}_{3}^{-} & \rightarrow \quad \mathrm{Fe}\left(\mathrm{HCO}_{3}\right)_{2} \\ & \mathrm{Fe}\left(\mathrm{HCO}_{3}\right)_{2} \rightarrow \mathrm{FeCO}_{3}+\mathrm{CO}_{2}+\mathrm{H}_{2} \mathrm{O}\end{array}$

This work was carried out to predict the reliability of the on-shore CCS site at Ketzin, Germany and to get a better understanding of the pit corrosion behaviour of steels used for $\mathrm{CO}_{2}$-injections. 


\section{Materials and methods}

Exposure tests in $\mathrm{CO}_{2}$-saturated aquifer brine were carried out using samples made of thermally treated specimen of $42 \mathrm{CrMo}-4(1 \% \mathrm{Cr}), \mathrm{X} 46 \mathrm{Cr} 13$ with $8 \mathrm{~mm}$ thickness and $20 \mathrm{~mm}$ width and $50 \mathrm{~mm}$ length. A hole of $3.9 \mathrm{~mm}$ diameter was used for sample positioning. The surfaces were activated by grinding with $\mathrm{SiC}$ Paper down to $120 \mu \mathrm{m}$ under water and dipping into acetone for ca. $5 \mathrm{sec}$. Samples of each base metal were positioned within the vapour phase, the intermediate phase with a liquid/vapour boundary and within the liquid phase $[20,21]$. The brine (as known to be similar to the Stuttgart Aquifer [24]: $\mathrm{Ca}^{2+}$ : $1760 \mathrm{mg} / \mathrm{L}, \mathrm{K}^{2+}: 430 \mathrm{mg} / \mathrm{L}, \mathrm{Mg}^{2+}: 1270 \mathrm{mg} / \mathrm{L}, \mathrm{Na}^{2+}: 90.100 \mathrm{mg} / \mathrm{L}, \mathrm{Cl}^{-}: 143.300$ $\left.\mathrm{mg} / \mathrm{L}, \mathrm{SO}_{4}{ }^{2-}: 3600 \mathrm{mg} / \mathrm{L}, \mathrm{HCO}^{3-}: 40 \mathrm{mg} / \mathrm{L}\right)$ was synthesized in a strictly orderly way to avoid precipitation of salts and carbonates. Flow control $(2 \mathrm{NL} / \mathrm{h})$ of the technical $\mathrm{CO}_{2}$ into the brine was done by a capillary meter GDX600_man by QCAL Messtechnik GmbH, Munic. The $\mathrm{pH}$ after the experiments was between 5.2 and 5.6. The heat treatment of the samples between $700 \mathrm{~h}$ to $17520 \mathrm{~h}$ was disposed in a climate chamber according to the conditions at the geological site at Ketzin/Germany at $60{ }^{\circ} \mathrm{C}$ at ambient pressure - each material in a separated reaction vessel. X-ray diffraction was carried out in a URD-6 (Seifert-FPM) with CoK $\alpha$-radiation with an automatic slit adjustment, step 0.03 and count $5 \mathrm{sec}$. Phase analysis was performed by matching peak positions automatically with PDF-2 (2005) powder patterns. Mainly structures that were likely to precipitate from the steels were chosen of the ICSD and refined to fit the raw-data-files using POWDERCELL 2.4 [25] and AUTOQUAN ${ }^{\circledR}$ by Seifert FPM.

The samples were cut partly for scale analysis with the corrosion layer. and prepared partly for kinetic analysis after the scale was etched. Descaling of the samples was performed by exposure to $37 \% \mathrm{HCl}$ for 24 hours and 3-D-images were realized by the double optical system Microprof TTV by FRT. Mass gain was analyzed according to DIN 50905 part 1-4.

Then the samples were embedded in a cold resin (Epoxicure, Buehler), cut and wet polished first with SiC-Paper from $180 \mu \mathrm{m}$ to $1200 \mu \mathrm{m}$. The finishing was done with diamond paste $6 \mu \mathrm{m}$ and $1 \mu \mathrm{m}$. Different light optical and electron microscopy techniques were used to investigate the layer structures and morphology of the samples.

\section{Results and discussion}

\subsection{Pit kinetics}

Pitting (local corrosion) and shallow pit corrosion are only observed on the specimen of X46Cr13 kept in the liquid phase (figure 2).

Pitting and shallow pit corrosion show a maximum intrusion depth rate around $4.8 \mathrm{~mm} /$ year (Figure 3) after $2000 \mathrm{~h}$, which is nearly half of the original pipe wall thickness of $11 \mathrm{~mm}$. In general the maximum intrusion depth of the phenomena related to shallow pit corrosion is greater than the pit depths. After 


\section{local corrosion pitting}

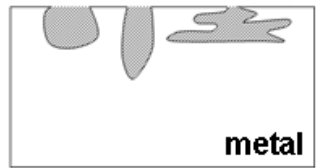

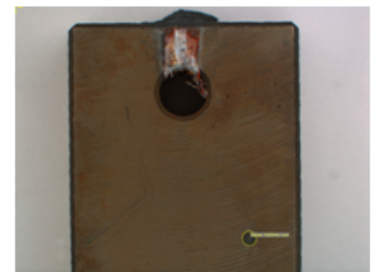

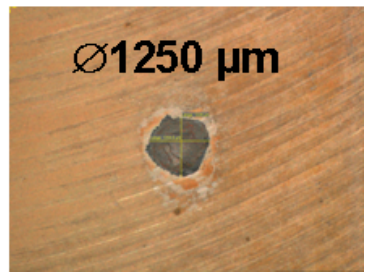

Figure 2: $\quad$ Example of pit corrosion on the sample surface of the $13 \% \mathrm{Cr}$ steel $\mathrm{X} 46 \mathrm{Cr} 13 \mathrm{kept}$ in the liquid saline aquifer brine for $8000 \mathrm{~h}$.

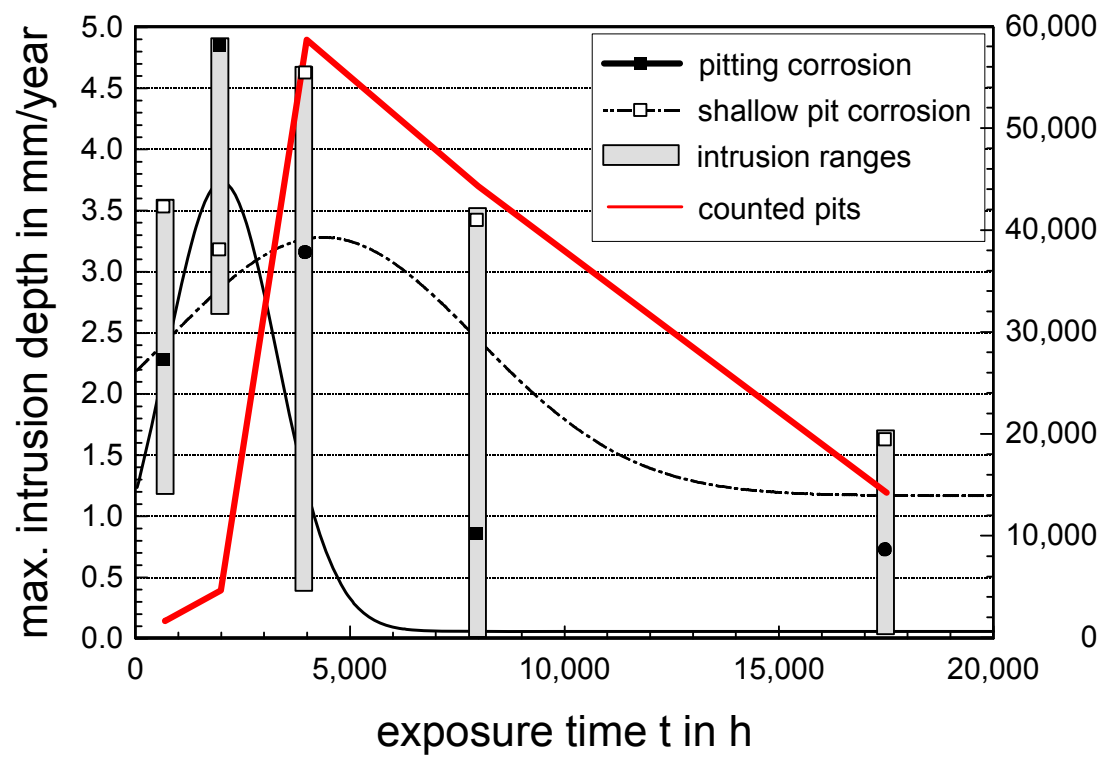

Figure 3: Intrusion depth and amount of counted pits of $\mathrm{X} 46 \mathrm{Cr} 13$ exposed to the solid phase liquid brine saturated with $\mathrm{CO}_{2}$ at 60 bar and ambient pressure. Here the maximum intrusion depths per year are demonstrated as a function of exposure time. A broad range of intrusion depths can be seen. After $8000 \mathrm{~h}$ nearly $1 / 3$ and after $15720 \mathrm{~h}$ nearly $1 / 2$ of the sample has been corroded, rather than showing distinct pitting or shallow pit corrosion.

$8000 \mathrm{~h}$ the velocity of the intrusion depth slows down and lower maximum intrusion depths are measured. Nearly $1 / 3$ of the specimen surface was corroded after approximately 1 year $(8000 \mathrm{~h})$ and nearly $1 / 2$ of the surface was corroded after 2 years $(17520 \mathrm{~h})$ rather than showing distinct pitting or shallow pit corrosion, because corrosion products prevent the access of corrosive media to the bulk material. Figure 3 compares all measured intrusions depths as a function of exposure time with the amount of counted pits. It reveals that the exposure time has little to no influence on the amount of counted pits per unit area. 


\subsection{Morphology}

Pit corrosion phenomena appear in samples with high $\mathrm{Cr}$-content (X46Cr13) only and moreover only on those samples that are exposed to the $\mathrm{CO}_{2}$-saturated liquid phase. This may be related to a locally disturbed passive layer or - more likely - to the difficulty to distinguish between local and surface corrosion on the low $\mathrm{Cr}$ bearing samples of $42 \mathrm{CrMo}-4$. Pits appear very soon after exposure to the corrosive environment and an example is demonstrated in Figure 4 where pits and shallow pit corrosion appear after 2 years of exposure in the $\mathrm{CO}_{2}$-saturated brine (liquid phase).

Optical 3-D-images of a characteristic sample part after descaling are shown in Figure 5. These demonstrate the severe influence of the pit corrosion and their initiating character by a great localized loss of volume in the vapour phase.
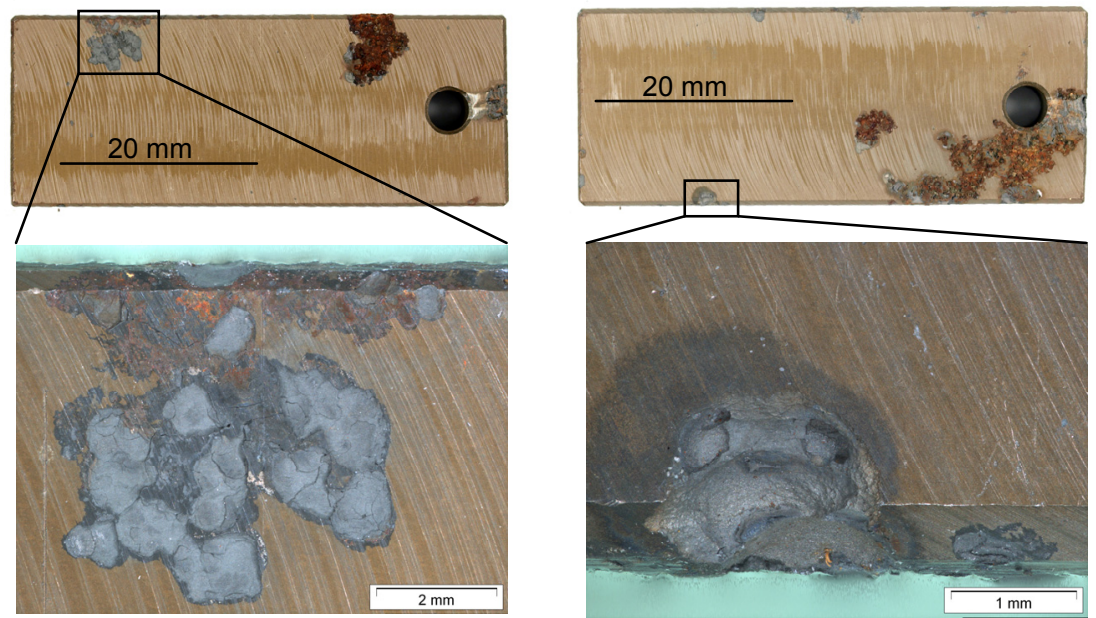

Figure 4: Example of pit corrosion on the sample surface of the $13 \% \mathrm{Cr}$ steel $\mathrm{X} 46 \mathrm{Cr} 13 \mathrm{kept}$ in the liquid saline aquifer brine for $17520 \mathrm{~h}$.
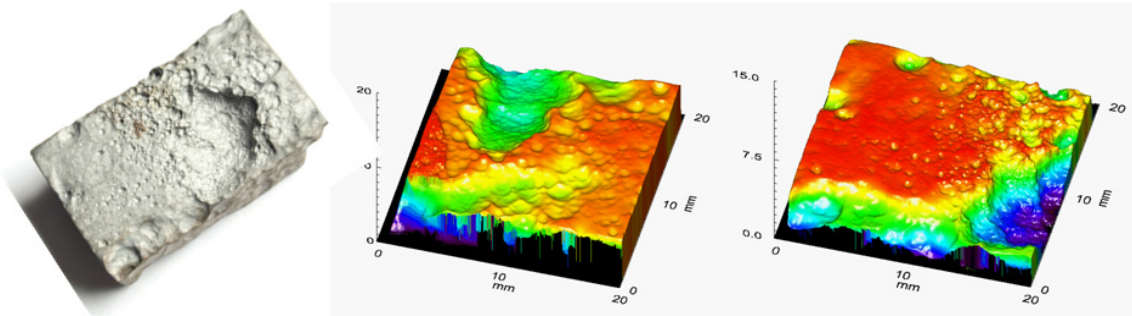

Figure 5: Surface image and optical 3D-Surface-Scan (Fa. FRT) of the sample X46Cr13 kept in the vapour phase for $17520 \mathrm{~h}$. 
Figure 6 demonstrates that the pits are covered with precipitates of the corrosion products formed on the surface elsewhere on the sample or on surfaces of samples that were kept in the vapour or intermediate phase.

The complicated multi-layered carbonate/oxide structure reveals siderite $\mathrm{FeCO}_{3}$, with small amounts of $\mathrm{Ca}$, goethite $\alpha-\mathrm{FeOOH}$, mackinawite $\mathrm{FeS}$ and spinel-phases of various compositions as the main phases (Figure 7). Lepidocrocite $\gamma$-FeOOH and akaganeite $\mathrm{Fe}_{8} \mathrm{O}_{8}(\mathrm{OH})_{8} \mathrm{Cl}_{1.34}$ are minor phases.
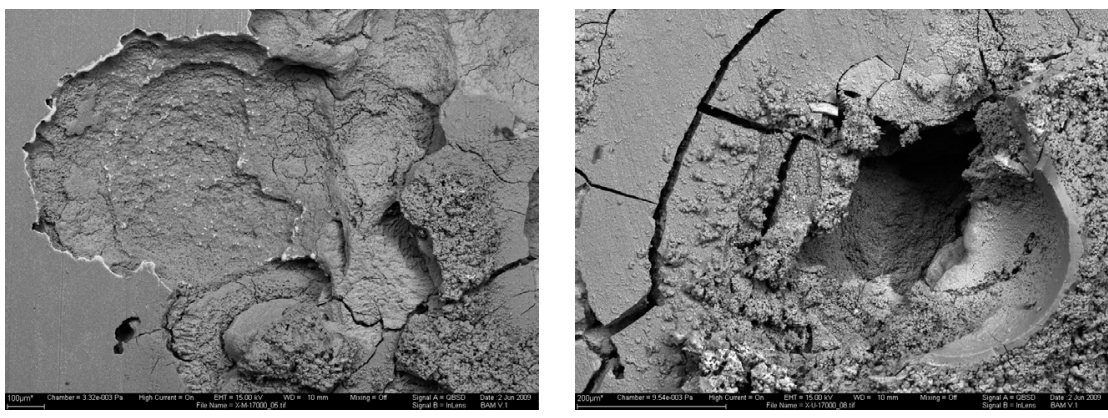

Figure 6: $\quad$ SEM surface images of precipitations on pits of the $13 \% \mathrm{Cr}$ steel $\mathrm{X} 46 \mathrm{Cr} 13 \mathrm{kept}$ in the liquid saline aquifer brine for $17520 \mathrm{~h}$ (left: liquid section of intermediate phase, right: liquid phase).
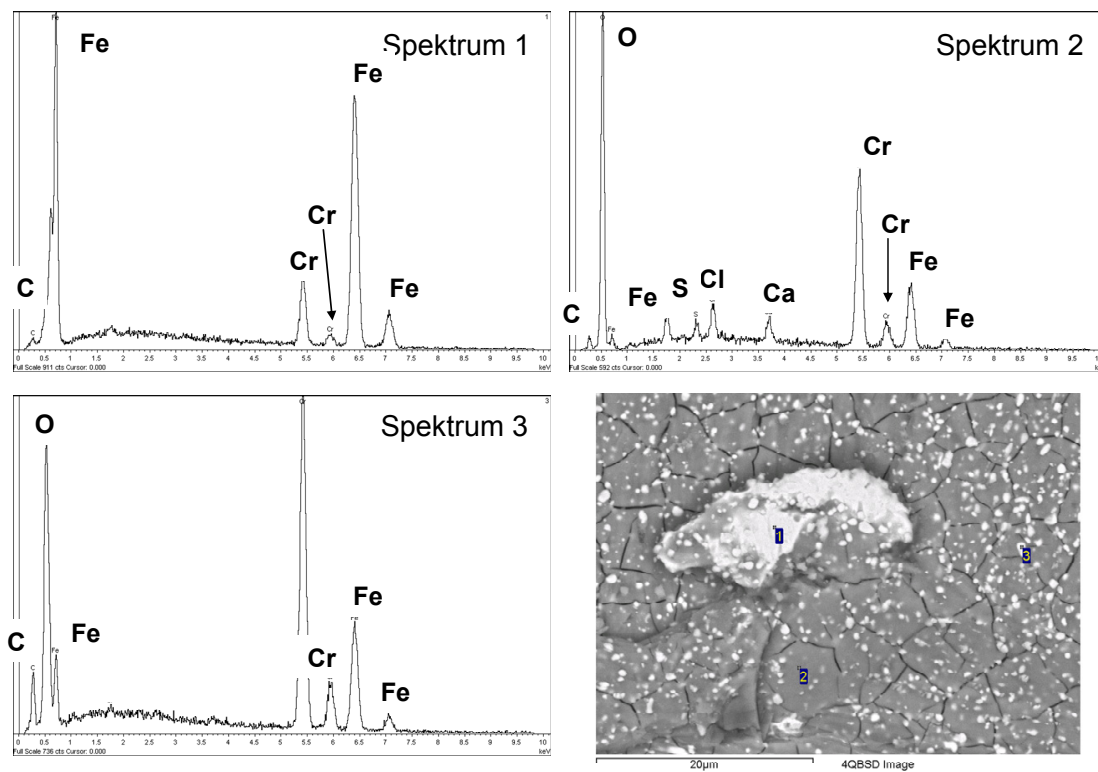

Figure 7: Cross section micrograph and EDX-spectra of pit surfaces of $\mathrm{X} 46 \mathrm{Cr} 13$ after heat treatment in $\mathrm{CO}_{2}$ saturated brine at ambient pressure for $17520 \mathrm{~h}$ (2 years). 
Similar to the high-temperature corrosion phenomena [26] carbides were identified within the corrosion layer. Following from thermodynamic calculations (Software FACTSAGE ${ }^{\circledR}$ ) $\mathrm{Mn}_{23} \mathrm{C}_{6}, \mathrm{Mn}_{7} \mathrm{C}_{6}, \mathrm{Fe}_{3} \mathrm{C}$ are stable phases under CCS-conditions.

\subsection{Pit corrosion precipitation}

Following from the results obtained above a corrosion prediction model may be developed (figure 8), which is related to the galvanic model described by Han et al. [23].

In the initial stage the steel is exposed to the corrosive environment, the $\mathrm{CO}_{2}$ saturated brine (a), where the carbon dioxide forms carbonic acid in contact with the aquifer water (b). A ferrous hydroxide passivating film can form when its solubility limit is exceeded (c).The formation of the scale in geothermal water takes place in 2 steps (d). The first step may be attributed to the formation of $\mathrm{Fe}[\mathrm{II}]$ compounds $\mathrm{Fe}(\mathrm{OH})_{2}[9,27]$ :

and in this case $13 \% \mathrm{Cr}$ steel

$$
\mathrm{Fe}+2 \mathrm{H}_{2} \mathrm{O} \rightarrow\left[\mathrm{Fe}(\mathrm{OH})_{2}\right] \mathrm{ads}+2 \mathrm{H}^{+}+2 \mathrm{e}^{-}
$$

$$
\mathrm{Cr}+3 \mathrm{H}_{2} \mathrm{O} \rightarrow\left[\mathrm{Cr}(\mathrm{OH})_{3}\right] \mathrm{ads}+3 \mathrm{H}^{+}+3 \mathrm{e}^{-}
$$

The formation of the scale leads to an increase of the local $\mathrm{pH}$ near the hydroxide film. Consequently a ferrous carbonate film may be formed accompanied by a set of rather complicated reactions leading to the formation of various phases (d). This corresponds to a second formation step of a magnetite spinel type with $\mathrm{Cr}$ content in the $13 \% \mathrm{Cr}$ steel and goethite [20] (d).

$2\left[\mathrm{Fe}(\mathrm{OH})_{2}\right] \mathrm{ads}+2\left[\mathrm{Cr}(\mathrm{OH})_{3}\right] \mathrm{ads}$

$$
\rightarrow\left(\mathrm{Fe}_{\mathrm{x}} \mathrm{Cr}_{(1-\mathrm{x})}\right)_{3} \mathrm{O}_{4}+\alpha-\mathrm{FeOOH}+4 \mathrm{H}_{2} \mathrm{O}+2 \mathrm{H}^{+}+2 \mathrm{e}
$$

and

$$
\begin{aligned}
{\left[\mathrm{Fe}(\mathrm{OH})_{2}\right] \mathrm{ads}+\mathrm{H}_{2} \mathrm{O} } & \rightarrow \alpha-\mathrm{FeOOH}+3 \mathrm{H}^{+}+3 \mathrm{e}^{-} \\
{\left[\mathrm{Fe}(\mathrm{OH})_{2}\right] \text { ads }+\left[\mathrm{H}_{2} \mathrm{CO}_{3}\right] \text { ads } } & \rightarrow \mathrm{FeCO}_{3}+2 \mathrm{H}_{2} \mathrm{O}
\end{aligned}
$$

Mackinawite $\mathrm{FeS}$ forms due to the saturation of the brine with $\mathrm{H}_{2} \mathrm{~S}$ and akaganeite $\mathrm{Fe}_{8} \mathrm{O}_{8}(\mathrm{OH})_{8} \mathrm{Cl}_{1.34}$ due to the high salt content of the brine.

Then the growth of the corrosion layer will proceed internally and externally, depending on the various carbon and oxygen partial pressures (e). Pit-formation may possibly be initiated at the carbide precipitates found throughout the early scale growth. Localized corrosion may then start when the ferrous hydroxide film (in its gel-stadium) is locally damaged due to mechanical or chemical effects (f). The highly porous ferrous carbonate, which does not lead to a passive layer with protection character, is then exposed to the brine environment where the $\mathrm{pH}$ is lower (f). As a result the ferrous carbonate film dissolves and the steel is locally depassivated (f). This is accompanied by corrosion and passive film dissolution in lateral direction $(\mathrm{g}, \mathrm{h})$ followed by the detachment of the carbonate film (i). The removal of the detached film causes the pit to grow wider, because the same steps will occur from the beginning on the newly exposed surface. 
a)
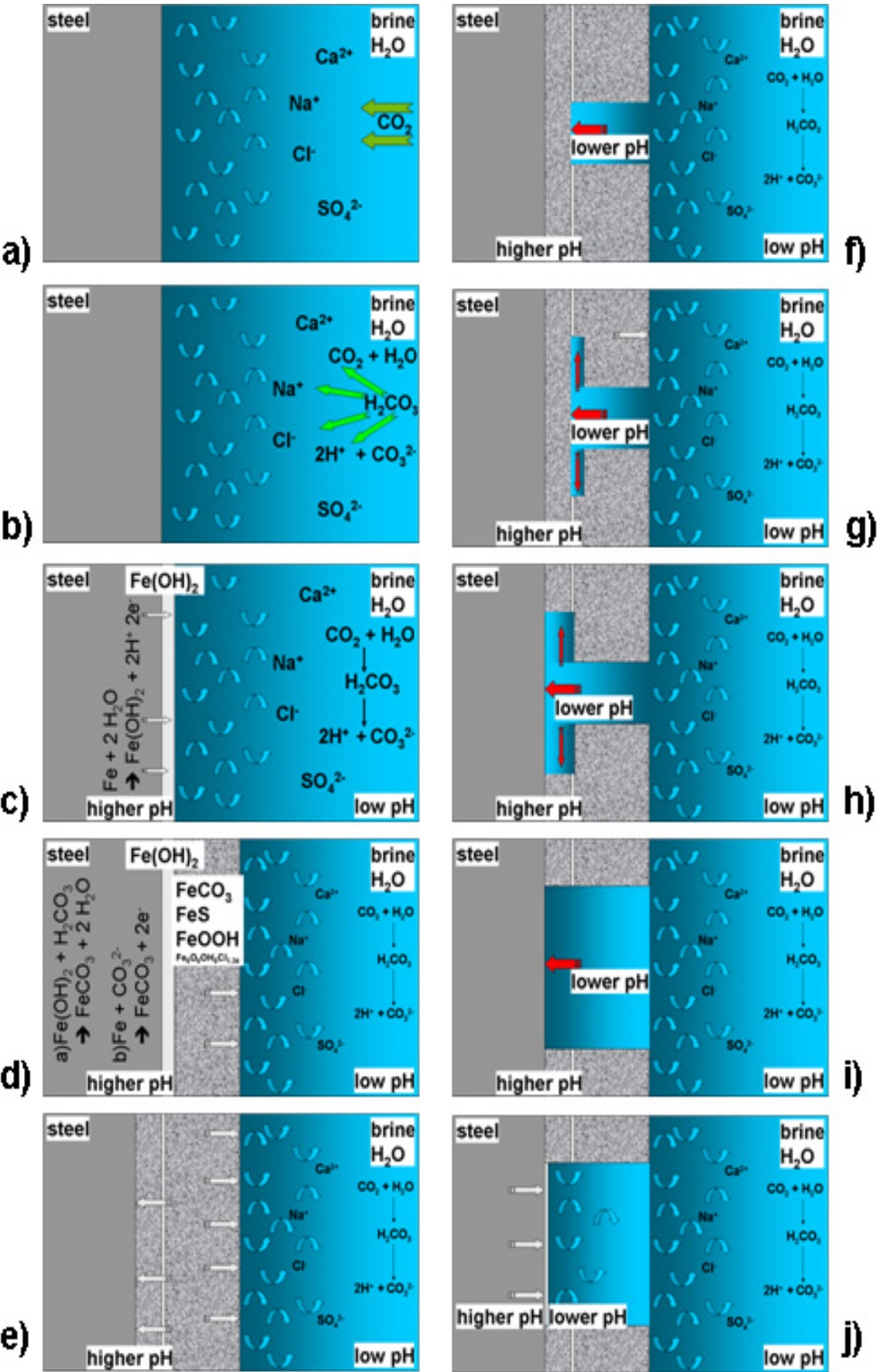

Figure 8: Possible formation mechanism of pits on the pipe steel $\mathrm{X} 46 \mathrm{Cr} 13$ related to the galvanic model described by Han et al. [23]. 


\section{Conclusion}

Severe pit corrosion with pit heights around $4.5 \mathrm{~mm}$ are located only on the $\mathrm{X} 46 \mathrm{Cr} 13$ steel kept in the $\mathrm{CO}_{2}$-saturated liquid brine where the gas flow and pressure is low. The formation steps of the corrosion scales and therefore the pitformation may possibly be initiated at the carbide precipitates $\left(\mathrm{Mn}_{23} \mathrm{C}_{6}\right.$ and $\left.\mathrm{Fe}_{3} \mathrm{C}\right)$ found throughout the early scale growth. Main phase of the continuous scale is $\mathrm{FeCO}_{3}$ siderite and goethite $\alpha-\mathrm{FeOOH}$ in both types of steel. A complicated multi-layered carbonate/oxide structure reveals, FeS mackinawite, lepidocrocite $\gamma$-FeOOH, spinel phases of various compositions and akaganeite $\mathrm{Fe}_{8} \mathrm{O}_{8}(\mathrm{OH})_{8} \mathrm{Cl}_{1.34}$.

During the carbon dioxide storage the $\mathrm{CO}_{2}$ is supposedly injected in the liquid or supercritical phase. Therefore there is no such pit corrosion expected as from the 2 phase situations stated in this paper. However, when there are intermissions of the injection it is highly recommended that the borehole is kept under pressure and inert gas phases to keep the formation water (brine) from rising in the injection pipe. If there is an aquifer water level in the borehole the initiation of pit formation as explained is very likely and has to be avoided. Pit growth cannot be calculated as easily as surface corrosion rates, because of its little predictability. Therefore it is not possible to give corrosion rates and lifetime predictions regarding pitting in CCS technology. Following from the worst case simulated here it is possible to count the days of intermission and calculate the pit growth rate with the highest penetration depth $(4.5 \mathrm{~mm})$. Also considering the NORSOK-Model is a safe way to predict corrosion rates from pitting.

\section{References}

[1] D.C. Thomas, Carbon Dioxide Capture for Storage in Deep Geologic Formations - Results from $\mathrm{CO}_{2}$ Capture Project, Volume 1: Capture and Separation of Carbon Dioxide form Combustion Sources, $\mathrm{CO}_{2}$ Capture Project, Elsevier Ltd UK 2005, ISBN 0080445748

[2] M. van den Broek, R. Hoefnagels, E. Rubin, W. Turkenburg, A. Faaij, Effects of technological learning on future cost and performance of power plants with $\mathrm{CO}_{2}$ capture, Progress in Energy and Combustion Science, Paper in Progress (2009) 1-24

[3] Y. Louafi, m. A. Ladjouzi, Effect of sulfide ions on corrosion behaviour of pipe steel in a simulated solution saturated with carbon dioxide, Journal of Solid State Electrochemistry, submitted manuscript: JS-D-09-00205 (2009) $1-26$

[4] S. Nešić, "Key issues related to modelling of internal corrosion of oil and gas pipelines - A review", Corrosion Science 49 (2007) 4308-4338

[5] G.H. Meier, W.C. Coons, and R.A. Perkins, Corrosion of Iron-, Nickel-, and Cobalt-Base alloys in Atmospheres Containing Carbon an Oxygen, Oxidation of Metals, Vol. 17, Nr. 3/4 (1982) 235-262 
[6] Impact of Mutual Solubility of $\mathrm{H}_{2} \mathrm{O}$ and $\mathrm{CO}_{2}$ on Injection Operations for Geological Storage of $\mathrm{CO}_{2}$, International Conference of the Properties of Water and Steem ICPWS, Berlin, September 8-11

[7] L. Strömberg, G. Lindgren, J. Jacoby, R. Giering, M. Anheden, U. Burchhardt, H. Altmann, F. Kluger, G.-N. Stamatelopoulos, Update on Vattenfalls`s 30 MWth Oxyfuel Pilot Plant in Schwarze Pumpe, Green House Gas Emission Reduction Technologies GHGT9 Conference, Washington DC, USA, November 16th to 20th, 2008

[8] L. Zhang, J. Yang, J.S. Sun, M. Lu, Effect of pressure on wet $\mathrm{H}_{2} \mathrm{~S} / \mathrm{CO}_{2}$ corrosion of pipeline steel, Paper No. 09565, NACE Corrosion 2008 Conference and Expo, New Orleans, Louisiana, USA, March 16th - 20th, 2008

[9] L.J. Mu, W.Z. Zhao, Investigation on Carbon Dioxide Corrosion Behaviors of $13 \mathrm{Cr}$ Stainless Steel in Simulated Strum Water, Corrosion Science, Manuscript No. CORSCI-D-09-00353 (2009) 1-24

[10] M. Bonis, Weight loss corrosion with H2S: From facts to leading parameters and mechanisms, Paper No. 09564, NACE Corrosion 2008 Conference and Expo, New Orleans, Louisiana, USA, March 16th - 20th, 2008

[11] J. Enerhaug, A study of localized corrosion in super martensitic stainless steel weldments, a thesis submitted to the Norwegen University of Science and Technology (NTNU), Trondheim 2002

[12] V. Neubert, Beanspruchung der Förderrohrtour durch korrosive Gase, VDIBerichte Nr. 2026, 2008

[13] R. Kirchheiner, P. Wölpert, Qualifizierung metallischer Hochleistungswerkstoffe für die Energieumwandlung in geothermischen Prozessen, VDIBerichte Nr. 2026, 2008

[14] H. Zhang, Y.L Zhao, Z.D. Jiang, Effects of temperature on the corrosion behaviour of $13 \mathrm{Cr}$ martensitic stainless steel during exposure to $\mathrm{CO}_{2}$ and $\mathrm{Cl}^{-}$environment, Material Letters 59 (2005) 3370-3374

[15] J.N. Alhajji and M.R. Reda, The effect of alloying elements on the electrochemical corrosion of low residual carbon steels instagnant $\mathrm{CO}_{2}$ saturated brine, Corrosion Science, Vol. 34, No. 11 (1993) 1899-1911

[16] Y.-S. Choi and S. Nešić, Corrosion behaviour of carbon steel in supercritical $\mathrm{CO}_{2}$-water environments, Paper No. 09256, NACE Corrosion 2008 Conference and Expo, New Orleans, Louisiana, USA, March 16th 20th, 2008

[17] X. Jiang, S. Nešić, F. Huet, The Effect of Electrode Size on Electrochemical Noise Measurements and the Role of Chloride on Localized $\mathrm{CO}_{2}$ Corrosion of Mild Steel, Paper No. 09575, NACE Corrosion 2008 Conference and Expo, New Orleans, Louisiana, USA, March 16th 20th, 2008

[18] Z. Ahmad, I.M. Allam and B.J. Abdul Aleem, Effect of environmental factors on the atmospheric corrosion of mild steel in aggressive sea coastal environment, Anti Corrosion Methods and Materials, Vol. 47 (2000) 215225 
[19] GeoForschungszentrum Potsdam, $\mathrm{CO}_{2}$-SINK - drilling project, description of the project PART 1 (2006) 1-39

[20] Pfennig, A., Bäßler, R. "Effect of $\mathrm{CO}_{2}$ on the stability of steels with $1 \%$ and $13 \% \mathrm{Cr}$ in saline water" Corrosion Science, Vol. 51, Issue 4 (2009) 931940,

[21] Pfennig, A., Kranzmann, A., "Influence of $\mathrm{CO}_{2}$ on the corrosion behaviour of $13 \mathrm{Cr}$ martensitic stainless steel AISI 420 and low-alloyed steel AISI 4140 exposed to saline aquifer water environment", Seventeenth International Conference on Modelling, Monitoring and Management of Air Pollution $20^{\text {th }}-22^{\text {nd }}$ July 2009, Tallinn, Estonia. Air Pollution XVII, Editors: C.A. Brebbia and V. Popov, Volume 123, (2009) 409-418 - WIT Press, ISBN: 978-1-84564-195-5, ISSN: 1746-448X

[22] http://www.standard.no/pronorm-3/data/f/0/01/36/9_10704_0/M-506d1r2. pdf, " $\mathrm{CO}_{2}$ corrosion rate calculation model"

[23] J. Han, Y. Yang, S. Nešić, B. N. Brown, Roles of passivation and galvanic effects in localized CO2 corrosion of mild steel, Paper No. 08332, NACE Corrosion 2008 Conference and Expo, New Orleans, Louisiana, USA, March 16th - 20th, 2008

[24] SW. Kraus and G. Nolze, POWDER CELL - a program for the representation and manipulation of crystal structures and calculation of the resulting X-ray powder patterns, J. Appl. Cryst. (1996), 29, 301-303

[25] A. Förster, B. Norden, K. Zinck-Jørgensen, P. Frykman, J. Kulenkampff, E. Spangenberg, J. Erzinger, M. Zimmer, J. Kopp, G. Borm, C. Juhlin, C. Cosma, S. Hurter, 2006, Baseline characterization of the $\mathrm{CO}_{2} \mathrm{SINK}$ geological storage site at Ketzin, Germany: Environmental Geosciences, V. 13, No. 3 (September 2006), pp. 145-161.

[26] A. Kranzmann, D. Huenert, H. Rooch, I. Urban, W. Schulz, W. Österle, Reactions at the interface between steel and oxide scale in wet $\mathrm{CO} 2$ containing atmospheres, NACE Corrosion Conference and Expo, Atlanta, 2009

[27] Banaś, U. Lelek-Borkowska, B. Mazurkiewicz, W. Solarski, Effect of $\mathrm{CO}_{2}$ and $\mathrm{H} 2 \mathrm{~S}$ on the composition and stability of passive film on iron alloy in geothermal water, Electrochimica Acta 52 (2007) 5704-5714 